\title{
A biblical death-wish: Paul celebrating dying in Phil 1:21 ${ }^{1}$
}

J Punt

(University of Stellenbosch)

\section{ABSTRACT}

\section{A biblical death-wish: Paul celebrating dying in Philippians 1:21}

Death features as an important concept in the Pauline writings in the New Testament for a number of reasons. However, the intriguing way in which the apostle at times addressed death as positive notion in itself, was traditionally related to Paul's theological convictions and his understanding of the death of Christ in particular. The remarkably pointed way in which Paul positively celebrated death in Philippians 1:21 borders on invoking a martyrological paradigm, and raises questions about his convictions regarding life, and bodily existence in particular. Interesting analogies emerge when Paul's celebration of death is compared in a concluding section with contemporary, popular instances where death is - even if for different reasons - presented as "gain".

\section{INTRODUCTION: DEATH IN THE NEW TESTAMENT, AND BEYOND}

It is almost a cliché to claim that death has been a major topic of interest and discussion in human societies from the earliest times. It is certainly true that death and also with what lies beyond death (cf recently Segal 2004), feature prominently in the New Testament, reflecting the interests of these documents but also representing the reflections of a certain era. The human fascination with death, and its inevitability, as well as what lies beyond the grave, has existed throughout human history and has been addressed in a multiplicity of myths and explanations. In a recent, popular novel by Elizabeth Kostova (2005) it is not the sensationalist account of the Dracula figure which features most prominently but the fascination with the end of life, or its prolongation by joining the ranks of the un-dead. Even stronger in focus, is how the Dracula myth unfolds amidst Medieval Christianity and its, mostly bitter, engagement with Islam - Count Dracula, or Vlad the Impaler is portrayed as having an

1 Paper read at the international All Souls conference on "Death and Beyond", arranged by the Amsterdam School for Cultural Analysis (ASCA), Amsterdam, 1-2 November 2007. 
intricate and uneasy but nevertheless constructive relationship with the (Eastern Orthodox) church. Also recently, in a statement which reflects human fascination with death, as much as human frustration with scientific ineptitude to provide explanations of death - and expressed in modern commercial metaphor - Ivan Illich is quoted as saying that the certainty of death is "the ultimate form of consumer resistance” (Parkes et al 2003:4).

In so far as the biblical documents provided an adequate reflection, people were no less fascinated and terrorised by death in biblical times. The understanding of death in the New Testament traditions was informed by the traditional insight regarding death in the Hebrew Bible, which was characterised by three dimensions, namely death as a "metaphor for those things which detract from life as Yahweh intended it", and "as a 'power' in opposition to the created order”, and "for biological cessation” (Bailey 1979:97-101) -in other words, death can have a symbolic, mythological or biological meaning. Others argue against such a tripartite division, blaming it for domesticating Hebrew Bible perspectives on death which generally saw death as posing a significant challenge to life: "Death can be understood and accepted as a natural part of God's order, but the people of the Hebrew Bible experienced individual and communal death, which was far more pervasive than biological cessation” (Richards 1992:108-110)2.

The New Testament authors to varying degrees portray knowledge of the Hebrew Bible through quotation, allusion and echo from its Greek-translation format, the Septuagint, but also provide evidence of assuming the world and values engendered by the Hebrew Bible ${ }^{3}$. In the end, however, regardless of the extent of the

2 The differences with the Greek world is telling, where death is ordained by God but subverted by the immortality of the soul which was privileged and emphasised. Plato in his description of the death of Socrates, refers to death as "a release and separation from the body" (Phaedo 67.D; cf 66.E), because the soul is immortal and imprisoned in the body (Phaedo 73.A and 82.E) and death amounts to the liberation of the soul from the body. Supported by the notion of reincarnation, death is restricted to the body alone, with the immortal soul sleeping (cf also Hesiod Theog 213; Diodorus Siculus 15,25.2) between its return to earth lives. Cf Gulley (1992:110-111).

3 For a fairly extensive consideration of how more than just quoting from the scriptures, Paul "lived" in his Bible, invoking and interacting with the Psalms, the prophets (Jeremiah, Ezekiel and Isaiah), and (other) Wisdom 
Hebrew Bible's influence and its diversity, the New Testament is characterised by much variety - in content, intensity, scope, effect and so on - as far as positions on and opinions about death is concerned. Even while as far as death is concerned in the New Testament the death of Christ has pride of place, these documents are generally concerned about death more generally as well. Given the considerable direct and indirect influence of Pauline thought(s) in the Western world, not the least through its appropriation in the reformed Christian tradition, the investigation of Paul's portrayal of death is important. In this paper, only one instance (Phil 1:21) is considered, mainly because death is presented in such a positive light in this text.

\section{DEATH AS AMBIGUOUS SCOURGE IN NEW TESTAMENT TIMES ${ }^{4}$}

While the New Testament authors interacted with and developed several emphases that emerged during the intertestamental times, the three forms in which death appears in the Hebrew Bible (metaphor, power and biological cessation) were incorporated into one, single force (Bailey 1979:87). Many alternative views on death are found in the New Testament but generally these authors ascribe more to death than simply the end of earthly life, and see it also as something capable of affecting life as its moves towards its end. Therefore and in somewhat ambiguous terms, while a living death is possible when someone lives as a "body of death" (Rom 7:24), an encounter with Christ presents eternal life during earthly or present life (Jn 3:26) as much as the absence of such an encounter is tantamount to being dead in sin (Eph 2:1; Col 2:13; Rev 3:1) - ultimately the transition from death to life is described as a new birth (Jn 3:3-8) ${ }^{5}$.

literature (Proverbs, Wisdom of Sirach and the Book of Wisdom), cf the study by Young and Ford (1987:60-84).

4 In the NT, the noun ( $\theta \dot{\alpha} \nu \alpha \tau o \varsigma$ ), adjective/noun ( $\nu \in \kappa \rho \rho^{\prime} \varsigma$ ) and verb $(\dot{\alpha} \pi \circ \theta \nu \eta \dot{\sigma \kappa} \omega)$ for death and dying are used, and while only God is immortal (1 Tm 6:16), the great leveller for all humans is death (1 Cor 15:21-22) since humans are mortals (Col 1:16; Heb 1:2) - the biblical exceptions Enoch (Gen 5:24; Heb 11:5) and Elijah (2 Kgs 2:11) prove the rule; as much as the promise of immortality with Christ's Parousia (1 Cor 15:53). Cf Bultmann (1967:892895); Gulley (1992:110-111).

5 Admitting some generalisation, the various influences upon New Testament authors are seen also in the different perceptions of death as 


\subsection{Paul's letters on death}

Although he was not the only ancient author to do so ${ }^{6}$, Paul reflected on death in his letters and it is probably his Romans 5-argument on how death came into the world that stands out in this regard. For him death had many reasons and authors, and was a scourge in a general sense, including but going also beyond problematic matters such as premature death, human limitations, or mortality as troublesome problems. He used death as metaphor for that in the world which breached the Creator's design, and since death was already made apparent and present in Garden of Eden, the world itself could be seen "as futile and death directed". Death in Paul becomes "the paradigm of all existence”, "demoralizing, challenging, and negating all human vitality and sense of purpose” (Bailey 1979:88). Paul may at times be accused of a rather morbid perception of life and death, especially when the ecclesiological warrant is removed from sections such as 2 Corinthians 4:7-12 which is easily renovated for categorical if not almost sentimentalist appropriation.

However, and again not only in the Pauline tradition but there in particular, death is also viewed through the lens of the resurrection of Christ, and death therefore receives an ambiguous status ${ }^{7}$. In the New Testament, Jesus is the first to be raised from the dead (Col 1:18; Rev 1:5), while seventy five other instances are found where

simultaneously an inescapable fate (ancient Greeks) but also judgement from God (Second Temple Judaism). Cf Kaiser and Lohse (1981:94-98).

6 For the ancient Greeks, death was most often seen as an inescapable fate as Plato made clear in his dialogue on Socrates' end (Phaedo 61-62); cf also in Epicurus’ Diogenes Laertius X.139; Epictetus, Enchiridion 7. Cf Kaiser and Lohse (1981:94-96).

7 In addition to the resurrection, the Parousia is also important for Paul's notion of death and life. In the traditional understanding, eternal life is the opposite of death in Paul's letters. Although eternal life is a possibility before the Parousia of Christ, a tension remains between the implications of Christ's death and resurrection (the "already") and the eschatological events ("the not yet"). A marker of this tension is death, "the last enemy to be destroyed" (1 Cor 15:26), and therefore eternal life in its full sense begins at the Parousia (1 Th 4:16-18). Cf Gulley (1992:110-111); Kaiser and Lohse (1981:154-158); in a different tone, cf Frederickson (2000:21-26). 
$\nu \in \kappa \rho$ ó $\varsigma$ ([the] dead) ${ }^{8}$ is the object of ' $\epsilon \gamma \in i \rho \omega$ (to lift up or awaken) or used with $\dot{\alpha} \nu \alpha \dot{\sigma} \sigma \alpha \sigma \iota \varsigma$ (raising or awakening). For Paul, specifically, it was the believer's connection with Christ which could not be separated by death (Rom 8:38-39), and that simultaneously repositions death which is variously described as being "at home with the Lord" (2 Cor 5:8), "gain" (Phil 1:21) and "to depart and to be with Christ” (Phil 1:23) (Bultmann 1967:893-894; Gulley 1992:110-111).

\subsection{Death and resurrection in Paul}

The reason for Paul's positive evaluation of death has usually been connected with the death and resurrection of Christ ${ }^{9}$, which provided Paul with a new understanding of death and life (Kaiser and Lohse 1981:105). The notion of resurrection which was already most often ascribed to apocalypticism was found to have been confirmed by the resurrected Jesus $^{10}$. Added to the resurrection, the imminent transition to another world, a new age, meant a different understanding of the world. Apocalyptic eschatology focused on confirmation and affirmation rather than poetic hope and aspiration. "Death has been defeated, although temporarily it continues to manifest itself biologically” (Bailey 1987:89). Paul perceived Jesus Christ as the exemplar and model to be followed, but even more importantly saw Christ as the enabler, the one through whom God initiated the new creation, the new 'adam to enable and empower the faithful, through his spirit ${ }^{11}$.

8 Nekрó is used literally, figuratively as well as sacramentally - the latter with reference to the appropriation of the death of Christ in the sacrament of baptism (Rom 6:11,13) (Bultmann 1967:894).

9 Cf Sabou (2005:5-41) for Paul's use of death as metaphor in Rom 6; and also for a useful overview on scholarship on Paul and death.

10 Nickelsburg also lists a general resurrection, together with the Parousia and the guiding presence of the Spirit of Christ as the three corollaries of the resurrection of Christ in Paul's mind. Paul's idea of the state of believers between their death and the Parousia is unclear, and in Phil 1:21-25 he only

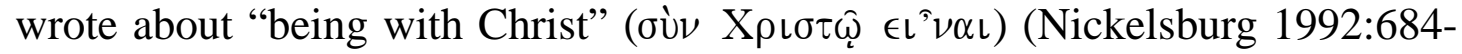
691). To see Phil 1:12-26 as primarily about Paul's perception of what happens to believers when they die (Coetzee 1984:335, cf 355) amounts to an overasking of this passage.

11 In the interest of space, suffice it to basically agree here with Collins (2002:373) that Paul did not simplistically subscribe to either a Jewish 
Unlike the situation in the Hebrew Bible, in Paul's understanding of death it was symptomatic of the fallen state; although he followed the Hebrew Bible in holding that the timing of individual death was important. Death is also not merely an attractive option to flee the world and its troubles ${ }^{12}$. "As a part of the world's paradigm which is passing away, it [death] loses its power to impel or to negate one's energies. It has lost its ultimacy” (Bailey 1987:91).

\section{PAUL'S “THEOLOGY OF DEATH AND DYING”}

While the death of Christ accompanied by his resurrection would naturally have been good reason for Paul to present death as more than simply a scourge, the consistently disapproving portrayal of death underlines his ultimately negative stance towards death. And given Paul's insistence that union with Christ is not dependent on

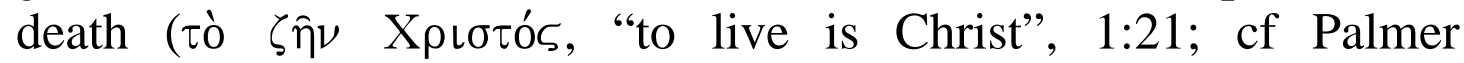
1975:203-218), the traditional explanation of Philippians 1:21 that death is gain because of its involvement in the establishment of union with Christ, has been challenged. It is furthermore surprising ${ }^{13}$ to find that Paul made such positive remarks about death in Philippians 1:21, particularly since there he did not reference his positive remarks directly to the death of $\mathrm{Christ}^{14}$. Pauline sentiments which appears to ascribe a positive or at least neutral value to death have to be compared with Paul's interpretation of death which sees it

perception of the resurrection of the body or a Greco-Roman notion of the immortality of the soul, but rather to the idea of the resurrection of the spiritual body, similar to the notion found in the books of Enoch and Daniel.

12 While death would have been a release for Paul in the Platonic sense, his desire for an even fuller union with Christ seems to have inhabited his positive pronouncement on death in Phil 1:21. Cf Daube (1962:104).

13 Although Paul did not mention death by the name, in 2 Cor 5:8 he also expressed the strong wish "to rather be away from the body and at home with

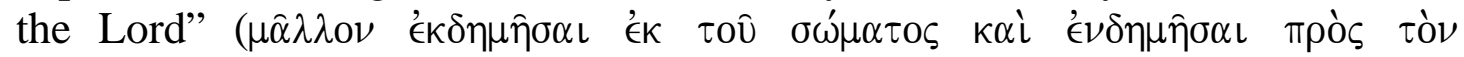
кúpเov).

14 The much debated Epistle to the Laodiceans (probably a 4th CE document, and a forgery attempting to fill the expectation created by Col 4:16) is clearly dependent on Philippians, and it is significant that one of the texts taken over directly was Phil 1:21: "For my life is in Christ and to die is joy" (v 8); cf "And what is pure, true, proper, just and lovely, do" (v 15; cf Phil 4:8); "That you may have the same love and be of one mind" (v 9b; cf Phil 2:2). 
as a foreign agent, and not originally intended by God ("The wages of sin is death", Rom 6:23; "Death came through a man”, 1 Cor 15:21; "Sin entered the world through one man, and death through sin”, Rom 5:12) ${ }^{15}$ (e g Gulley 1992:110-111).

Paul's theological convictions evidently developed in accordance with his background (Keck 2006:109-122), and the ambiguity which are present in Paul's thinking, reflects the different influences on it. The anthropology of Israel over the centuries implied that the life of the human being, composed of body and soul or breath in an organic unity essential for life (Gen 2:7-8), came to an end when the breath which was on divine loan was taken back (Ps 104:29-30; Qoh 12:7) and the body returned to the earth (Gen 3:19; Ps 90:3). Since the person was not comprised of a perishable or fleshly body and an immortal soul, the resurrection implied a bodily resurrection. However, a link could be maintained between the dead and the living, but this was accomplished not through the position or location of the deceased individual but by his [sic] sons and descendants. Israel lived on in continuity with and through the ancestors (Martin-Achard 1992:680-684) ${ }^{16}$. However, on the other hand, Paul's understanding of the death and resurrection of Christ meant that he found in the Greco-Roman ${ }^{17}$ notion of the continuation of life beyond death a useful conceptualisation with which to portray the position of the believer who passed away.

\subsection{Choosing between life or death in Philippians}

Paul's positive-sounding sentiments on death in Philippians 1:21$26^{18}$ is therefore a complication in his otherwise disapproving

15 And in Revelation, the deadly consequences of death is radicalised when it is also linked with God's judgment (Rev 2:11; 20:6; 21:8).

16 It is interesting that no direct quotations from the Scriptures of Israel (or LXX) are found in Philippians although there is general agreement that Phil

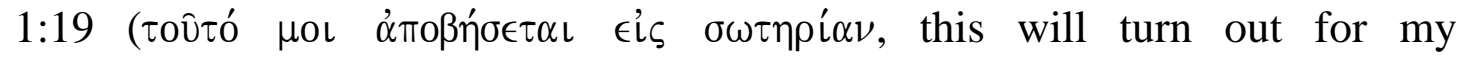
deliverance) partly invokes LXX Job 13:16. Cf Croy (2003:519); Hays (1989:21-24).

17 Daube (1962:101) argued that Paul was as much as Philo and the Essenes influenced by Platonic thinking on death as a release from earthly troubles.

18 Phil 1:21-26 is the culmination of a longer section (1:12-26) where Paul dealt with the relationship between his imprisonment and the proclamation of the Gospel, and in which his argument is finally decided in favour of life and 
position on death, particularly since he did not provide any indication that in the end he could tolerate death as a legitimate expression of the will and wisdom of the Creator of life. In fact, Paul rather presented mortality as an infringement upon and ultimately a distortion of the will of the Creator (Bailey 1987:88-89). The rationale for Paul's enigmatic claim that dying would for him be

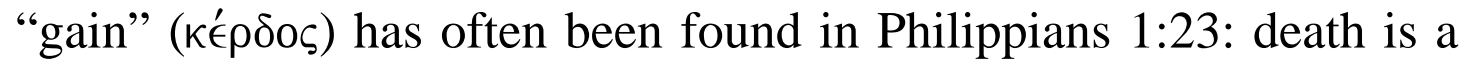
way to achieve union with Christ in a way that he evidently did not believe to be possible to the same extent while he was still alive.

Death for Paul was therefore positive not as an event in itself, but rather as a means to an end, "to be with Christ"19. In Philippians 1:21 Paul emphasised that it was his desire to die and "be with Christ" rather than to continue living. After noting that continuing

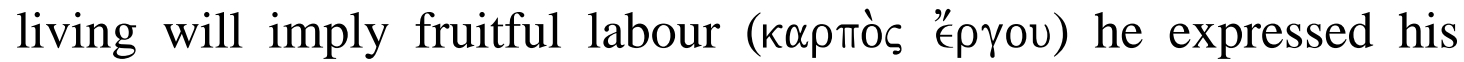
inability to choose, or at least his indecision (oủ $\gamma \nu \omega \rho i \zeta \omega$ ) in 1:22. In the next verse he made his preference very clear, namely to "depart

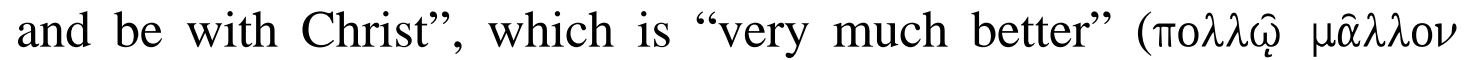
$\kappa \rho \in \hat{\tau \sigma \sigma o \nu}$ ). But in 1:24, practical necessity wins the day: it is "more

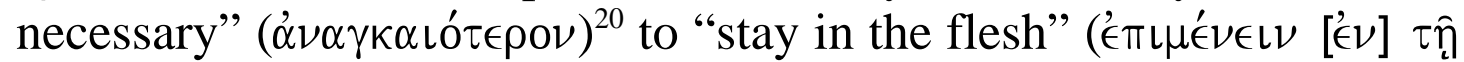
$\sigma \alpha \rho \kappa i)$. And Paul concluded his thoughts on this topic with a strong

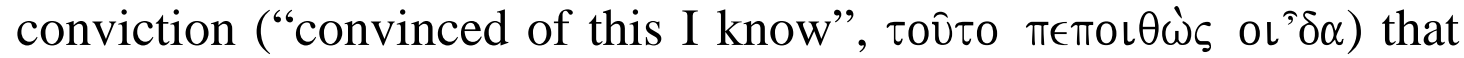
he should remain alive so that he could serve the Philippians and others $^{21}$ : he will "remain and continue" ( $\left.\mu \in \nu \hat{\omega} \kappa \alpha i \quad \pi \alpha \rho \alpha \mu \in \nu \hat{\omega}\right)$ with

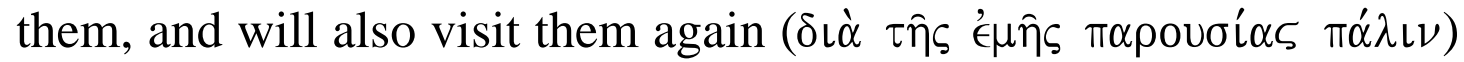
in the near future (1:25-26). Clearly Paul's preference is for dying

furthering the gospel although the preferred option remained death and being

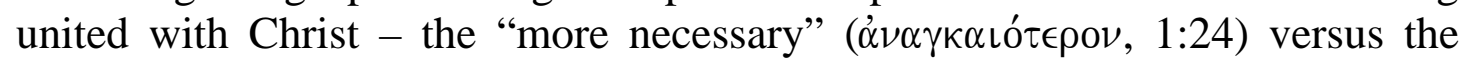

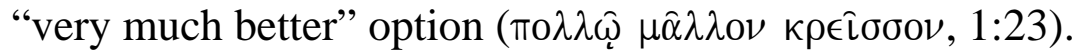

19 Droge's argument that Paul valued death also as a way of achieving immortality can hardly be sustained from the text (Droge 1992:225-231).

20 Pursuing the argument of Plato that Socrates considered voluntary death only proper if there was some anagke or divine necessity (Phaedo 62c) for such

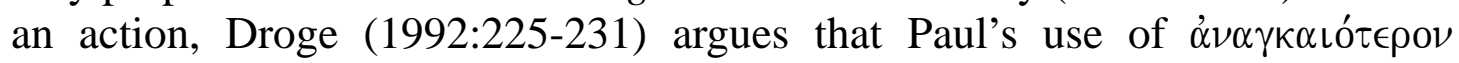
suggests that the constraint that prevented him from taking his own life was his perception of the continuation of his earthly mission as God's will.

21 The Roman Stoic, Musonius Rufus, also expressed the notion that (voluntary) death should be to the benefit of others (frag 29; cf Droge 1992:225-231). 
even if he in the end decided upon life as the necessary and practical option $^{22}$; but the question remains: why celebrate death?

\subsection{Death as martyrdom in Philippians?}

In expressing his willingness to die and even his preference for death over life in Philippians, Paul was in the past at times seen to assume the role of a martyr (cf Tabor 1992:574-579). It has further been suggested that Paul's references to death in Philippians 1:21-26 was his anticipation of a possible negative outcome of his impending trial in his place or incarceration ${ }^{23}$. It is of course possible to understand Philippians 1:21 within a martyrdom paradigm, and some scholars have argued that Paul held that the mystical identification of believers with Christ entailed that they were all martyrs -also qualifying for the rewards of martyrdom (Segal 2004:424). Although other texts, perhaps even more than Philippians 1:21 suggest a martyr context ${ }^{24}$, no martyrological paradigm is present in Paul's letters ${ }^{25}$.

In his letters, and even in the instances where death is not primarily indicated negatively, Paul nevertheless did not expound the praise of voluntary death as a goal in itself, nor did he present any elaborate polemical defence thereof. Paul's own experiences and behaviour, however, as claimed in his letters (cf 2 Cor 11:23-33; 1

22 The rhetorical force of Phil 1:21-26 is not that of a theological treatise or self-assurance in the face of the terror of imprisonment but Paul's confident tone is an indication that he intended to console the Philippians (cf Crossan and Reed 2004:273-4).

23 Various suggestions as to the provenance of the letter, which is commonly accepted to have been written by Paul from prison (e g the references to his “chains”, Phil 1:7, 13, 14, 17), have included Rome, Ephesus and Caesarea.

24 In Phil 2:17-19, 23-24 the possibility of Paul's execution is strongly present again, although he again discounts that possibility in his hope for divine deliverance. Elsewhere in the Pauline corpus, it is 2 Cor 4:8-10 (cf above) that comes closest to Phil 1:21.

25 Unlike the rest of the NT: Jesus is called a faithful martyr in Rev 1:5 and $3: 14$, but is certainly also presented as such in the Gospel where the voluntary nature of his death is stressed (e g Jn 10:18; Mk 8:31-33; Mt 16:21-23; Lk 9:51), while some scholars argue that Paul's portrayal of Jesus' death was apparently influenced by the Maccabean materials (e g Tabor 1992:574-579). Daube (1962:87), however, saw a gulf in Jewish thinking between suicide and being put to death by others. 
Cor 15:9), illustrate the assumption that (the willingness) to die for one's faith was noble - a notion supported by accounts found in Acts (e g 10:23-25; 14:5, 19; 17:6-10; 21:30-31; 22:22-23; 23:21). However, if for Paul death was not a "desirable escape from the world” (Bailey 1987:91) Paul supposed advocacy of martyrdom is difficult to maintain, quite unlike Hellenistic literature and martyrdom descriptions in Intertestamental literature. Then again, if the choice between life and death was not imposed upon him by others but was a matter of his own volition, it is understandable that his internal struggle could be interpreted as being concerned with suicide.

\subsection{Death as suicide in Philippians?}

The way in which Paul put his dilemma regarding dying forward in Philippians 1:21-26 has led some scholars (cf Droge 1988:262-286) to believe that Paul considered suicide ${ }^{26}$, reflecting Greco-Roman philosophical arguments on the appropriateness of suicide which were often linked to the discussion of the death of Socrates. Religiously motivated suicide is a rather sensitive issue in the history of Jewish and Christian thought, and was of course not unrelated to issues of martyrdom and redemptive suffering generally. Both in the sense of wishing to escape earthly troubles and the mortality of the body in particular, as well as the longing for immortality by reuniting with the divine meant that, with sufficient warrant and reason, suicide was not necessarily perceived in a negative sense in

26 In the NT it is only the death of Judas which is a clear case of suicide, and it is simply noted without condoning it or condemnation - as in the case with suicides in the Hebrew Bible (e g Abimelech in Jdg 9:54, Samson in 16:29; King Saul in 1 Sam 31:4, Saul's armour-bearer in 1 Sam 31:5; Ahithophel in 2 Sam 17:23; Zimri in 1 Kgs 16:18; cf Eleazar in 1 Macc 6:43; Ptolemy Macron in 2 Macc 10:13; and Razis in 2 Macc 14:37). Judas’ suicide is presented as an act of remorse and repentance and not a transgression; the latter accusation would only be made by later theologians. In another reference to suicide, Ac 16:27-28 presents Paul as having prevented the suicide of his Philippian jailor in order to convert him. Cf Daube (1962:82-104); Droge (1992:225-231); Koch (2005:168). For a dissenting position, cf Croy (2003:530) who holds that ancient views on suicide were not consistently approving of it, only under extreme circumstances; that the biblical texts either condemn or remain silent about its morality; and, that Paul's letters provide no evidence that he was psychologically inclined towards suicide. 
the contemporary Greco-Roman context ${ }^{27}$. In both the Hebrew Bible and the New Testament, stances towards suicide did not amount to the negative reputation suicide gained later in the church's theological arguments ${ }^{28}$.

The case for Philippians 1:21 reflecting a suicidal Paul hinges on the interpretation of 1:22 and 1:23, since in the former his ability to choose ( $\tau i$ $\alpha i \rho \eta \dot{\sigma o} \mu \alpha \iota$ ) argues against his imminent execution by the authorities ${ }^{29}$, and the latter his having a strong desire to depart or die ( admitted that Paul did not reject suicide per se (Droge 1992:225231), it is a question whether Philippians 1:21-26 should be understood in the sense that Paul did not consider it the appropriate time for taking his own life.

In short, theories about Paul's perceptions on and inclinations towards martyrdom and the related notion of religiously motivated suicide are informative and helpful for moving the argument beyond the tepid traditional notion of union with Christ as rationalisation of death. But these theories are also not exhaustive of Paul's rationale for advancing his own death or sufficiently textually grounded to warrant them as sufficient explanation of Paul's positive perspective on his own death ${ }^{31}$.

27 Cf Epictetus' appeals to young men contemplating suicide in Plato's Phaedo 1.9.13-16.

28 While suicide is certainly not promoted in the Bible since human life is generally considered to be a gift from God, no law condemning suicide is on the other hand found in the Bible. Cf Koch (2005:167-172).

29 Further supported by his strong conviction that he will be able to continue his relationship with them and even to visit them in the near future (Phil 1:24-26).

30 Paul's death wish finds some contemporary correlation in Seneca's libido moriendi in Ep. 24.25. It is not clear how Paul eventually died, whether by his own hand, or by execution by the authorities as the tradition holds.

31 Objections against the theory that Paul viewed death as gain since it brought relief from earthly troubles include Paul's insistence upon the value of suffering for Christ, borne out by Epaphroditus' suffering and prospect of death which was not presented as escape from a troublesome existence, and, being with Christ is left ambiguous by Paul. That Paul contemplated suicide makes too much from $\epsilon \pi \imath \theta u \mu i \alpha$ if it is understood as lust for death, also since Paul did 


\section{CELEBRATING DEATH: PAUL'S DEATH-WISH IN PHILIPPIANS 1:21 $1^{32}$}

Paul's positive reference to death in Philippians 1:21 should be understood amidst and within its wide range of first-century contemporary influences, and primarily within the largely theological argument it forms part of: the traditional theological notion of union with Christ, and more recent martyrdom and suicide theories all succeed only in highlighting certain aspects of Philippians 1:21. In Paul's argument, various and at time different ideas and perceptions relating to socio-cultural, socio-political and religious paradigms and worldviews came together, and raised questions about his convictions regarding life, and bodily existence in particular. His argument was rhetorically forceful, aimed both at strengthening the ties between Paul and the Philippians, but also to comfort and reassure them amidst his own less than favourable situation. Reinforcing at discursive level his commitment to the Philippians by means of a rhetorical strategy of dubitatio ${ }^{33}$ (Croy 2003:529), the celebration of death lurks in the background.

Regarding Paul's rhetorical celebration of death, it would be an injustice to his argument if it is not placed in its apocalyptic context with an imminent expectation of the end of things as they were at the time, and if it fails to relate Paul's death-wish with his belief in $\mathrm{Christ}^{34}$. But the broader socio-historical setting, aspects of which

not use death but "to depart" ( $\dot{\alpha} \nu \alpha \lambda \hat{v} \sigma \alpha \iota)$ but most of all since his desire is unity with Christ and not death itself (Croy 2003:522-252).

32 An earlier predecessor of Paul, Epicurus, reasoned that death should not prove to be a concern, for the simple reason that there is no afterlife, obliterating the need to be concerned about either death or its consequences. " $\mathrm{A}$ right understanding that death is nothing to us makes the mortality of life enjoyable not by adding to life and illimitable time, but by taking away the yearning after immortality" (Epicurus, quoted in Walter 2003:169; cf Perkins 1988:123).

33 Croy (2003:525-531) argues that Paul's argument relies on "feigned

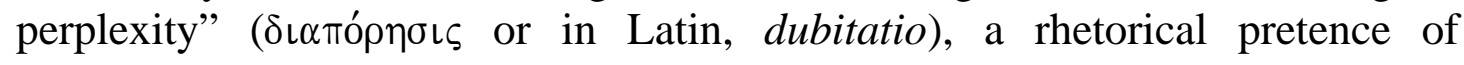
uncertainty in order to strengthen the argument.

34 Croy's insistence that Paul's concern was "chiefly located in his rhetoric, not in his legal predicament or his psychological state" and also that Paul did not believe himself to have been in mortal danger because of the accusations for which he was imprisoned or by extension despondent to the extent that he contemplated death by his own hands (Croy 2003:529), seems unnecessary 
were referred to above, are also important so as to place Paul's positive words on death amidst a pervasive first-century CE pessimism $^{35}$ and the reigning (and sometimes diverging) Jewish and Hellenistic notions regarding death, and general philosophically inspired notions on non-attachment and passionlessness.

While Paul also shared in the pessimistic outlook of his time, a cosmic fatalism, which he even radicalised to include the whole world in "a state of unfreedom" (Betz 1977:8), his letters do not show an exclusively negative view of the world or consistent worldescapist notions ${ }^{36}$. His anthropology differed from the contemporary Greek-philosophical position of an "unchangeable physical/ metaphysical state of being" which existed as the result of "mythicohistorical events", aspects of which emerge in his letters as for example in Romans 5 (Betz 1977:6). In Paul's case it was his strong apocalyptic framework which necessarily challenged an overbearing concern for this life and its accompaniments, especially since an apocalyptic mode of thought was necessarily cosmic, and thus also about power and control, of the world, of people, of all that exists. On the other hand, the Jewish apocalyptic framework included the notion of the resurrection of the faithful, which could have softened pessimism about the end of earthly life to some extent.

restrictive. Paul's rhetoric was most probably generated by his circumstances and informed by the socio-cultural influences bearing upon him. Cf also Schreiber (2003:336-359).

35 The first-century world was characterised by a pessimistic worldview, and to which the general sense of socio-political powerlessness certainly have contributed. The erosion of the classical Greek polis-system, "characterised by pessimism, distrust of reason, new age visions, withdrawal from the political to the individual world, a longing for lasting values and authority, and susceptibility to various kinds of religions and superstitions" (Luz 1994:12) can be likened to the modernist yearning for hope in a hopeless world.

36 The nature and tone of 1st CE Judaism has in the past been discussed with reference to the Pauline discourse against Jewish legalism which according to Montefiore was not directed against the "more warm, positive, and lifeembracing" Palestinian Judaism, but rather at the Diaspora version of Judaism with a "pessimistic view of the world and human nature, and its legalistic attitude toward the Law" (Howell 1993:322). For the difficulty in maintaining the differences or even opposition between Palestinian and Hellenistic Judaism in light of recent research, cf e g Lieu, North and Rajak (1992:1-8); Murray (1982:194-208). 
Amidst the complexities of first-century opinions on death and beyond, Paul accorded death an ambiguous position, for two reasons. Firstly, death was relativised in Paul's argument which assumed the death of Jesus Christ as paradigm, and presupposed that the mimicking of Christ's death was not worthless. Since he believed Jesus Christ overcame the all-consuming and life-alienating power of death through his resurrection, death is portrayed as a power overcome, a battle fought and won. Secondly, death became a mediating and enabling factor for Paul, connecting Christ and his followers, challenging the socio-political structures of the time through celebrating Christ's but also his, eventual, death ${ }^{37}$. Death very much remained part of human existence, but could at times be celebrated for its critical, enabling function - that is, amounting to more than establishing unity with Christ, Paul's death-wish is a challenge to the structures of the world and the boundaries of human existence.

\section{PAUL IS DEAD; LONG LIVE PAUL! CONTEMPO- RARY DEATH WISHE(R)S}

While death in contemporary society is generally bemoaned ${ }^{38}$, especially in situations of what is seen as unwarranted or "unnatural" death through violence, warfare, poverty and disease and the like, instances where death is celebrated in the popular media raise interesting questions. Contemporary discussions about death are often referenced to largely non-theological arguments, which are ironically nevertheless still "religious" in the sense of being both metaphysical and connecting with the deeper questions of life and

37 In this regard also, Paul turned the world on its head. Cf Georgi (1991).

38 The importance of death and afterlife is of extreme importance in Southern Africa, and in fact, for Africa as a whole, given the widespread significance of ancestor veneration and the professed presence of ancestors in the daily lives of people. In the African society the role of the community in daily life is central (Olson 1991:274). The extended family forms the basis of family life, and is, together with the ancestors and those still to be born, part of the community. The strong sense of humanity at large being one community implies also that no person is a stranger (Shutte 1988:4). However, how do such considerations survive amidst rampant and violent crime in SA that sees even the most vulnerable of society, even babies, being the victims of rapists and murderers. And what went wrong that violence caught on so easily? 
human existence amidst our secular, commoditised postmodern twentieth-first century.

\subsection{Religious secularisation of the world, and death}

Paul's successors in the Christian church, and the Protestant formation in particular, has with its emphasis on biblical religion effectively succeeded in demystifying and secularising the world outside the Bible. With a radical separation between God and humankind, and between humankind and the natural world, something of the hierarchical order of biblical times was maintained while - unlike perceptions of biblical times - the presence of spirituality was no longer conceivable in the world.

Particularly since the Enlightenment, the disavowal of the influence of spiritual forces in nature was joined by the conviction that nature in fact proceeds in orderly fashion through its own laws and according to its own rhythm. Such changed perceptions meant a different approach to, among others, death, which now ceased to be capricious but became predictable and prescribable: "Death, like the rest of nature, became disenchanted". Death was increasingly seen to be a natural process rather than spiritual passage, and by the twentieth century death has been thoroughly medicalised since it was no longer seen as much a human condition as it was a medical problem (Walter 2003:175-177).

\subsection{Contemporary death wishe(r)s: Struggling with death today}

While space does not allow for an exhaustive treatment, it is in popular Hollywood movie-culture where death - especially induced death - has at times become more than a medical problem and is also presented as gain, as profitable, although mostly the death of the Other rather than the Self except in the case of the martyr-like or self-sacrificial death ${ }^{39}$. With the representation of values in contemporary society increasingly determined by popular media rather than religious institutions (cf Miles 1996:25), films offer a repository for current values, and so also demonstrate (some)

39 But, as Jasper who sees film as escapist at best rather grudgingly admits, the bonds between society and religion cannot be severed totally, not even in a postmodern age where both church and popular sensitivities augur against the unsystematic, the inconsequential, the inchoate of life today (Jasper 1997:237, 39). 
modern understandings of death. In the Charles Bronson movies in the Death Wish-series, for example, a relatively well-to-do businessman is portrayed as someone who decided to take the law into his own hands after his family members were violated by street criminals. In typical vigilante style Bronson goes in search for the perpetrators but after a short while, other criminals are also included in his execution-style punishment. While these movies were to some extent a reflection on society's reaction to as well as helplessness towards rampant crime, they also harboured the ambivalence of using violence to destroy violence, a death-wish in all its ambiguity - a persuasion as much as a tactic that characterise the American mind particularly, if not exclusively.

Moreover, in movies on the popular, mainstream circuit, death is sometimes portrayed as a relativisation of current existence. All things being equal and not considering exceptional instances, in Hollywood movies technological and medical efforts are generally focused on the prolongation rather than the termination of life, which makes the portrayal of death as enabling even more significant. The tendency towards redemptive violence ${ }^{40}$ in the Scorsese-movies (Deacy 2001:104-137) includes violence but invariably also death as redemption. Here it is not necessarily about death as the conduit, the means and method of arriving in or achieving afterlife, but death rather becomes the ultimate verifier of a life lived fully: death retrospectively sanctifies the past life.

Different than in Paul, death can now indeed become a goal in itself; or maybe, as in Paul, death becomes the signifying event of something else, of its very opposite, of life. In both Paul and Scorcese death and life are inseparable: for Paul, death and (after)life are entangled, whereas in Scorsese's Hollywood presentation, death and (earthly) life are entangled ${ }^{41}$. In both cases though, death is what gives (brings out) meaning and is that which validates, legitimises and redeems.

40 Cf Wink (1992) regarding the (USA but also global) society's portrayal of violence and death as the solution to problems, especially problems with other people: the focus falls on the redemptive possibilities of death rather than celebrating death as such.

41 "As in the case of Christianity, redemption thus proceeds not from an escape from reality but from a more resolute confrontation with the truth and the actuality of the human condition” (Deacy 2001:54). 


\section{CONCLUSION}

In the Western world people have been alienated from more of less anyone's death but their own - and then only by default! - given health care systems which relegate death to the specialised and at times "private" space of a hospital, hospice or even (old age) care facility on the one hand, and on the other hand the domestication of death in popular and at times sensationalist media. In (Southern) Africa, things look somewhat different, and death is often an event experienced by the whole, extended family in their home, and here the liberalisation of death (as e g by Hollywood) at times competes with the superfluity or excess of death as the result of disease, exposure, and violent crime.

A few things about Paul and death, at least in Philippians 1, have become clear. His celebration of death should not be interpreted, along fairly simplistic lines, as either merely nostalgic religious sentiment, as idealistic or in pragmatic sense as a (individual) attempt to change his personal history. His comments on death should be understood as being connected to his concern for the Philippians and understood in relation with Christ. But further, amidst the full ambiguity it implies, death at times became a mediating or mediatory factor for Paul in a world characterised by apocalyptic violence and oppression. Such elements and ascribing death a mediatory role in particular can provide an interesting interface with modern perceptions of death.

\section{Consulted literature}

Bailey, L R sr 1979. Biblical Perspectives on Death. Overtures to Biblical Theology. Philadelphia: Fortress.

Betz, H D 1977. Paul's Concept of Freedom in the Context of Hellenistic Discussions about the Possibilities of Human Freedom. in Wuellner, W (ed), Paul's Concept of Freedom in the Context of Hellenistic Discussions about the Possibilities of Human Freedom. The Center for Hermeneutical Studies in Hellenistic and Modern culture, Protocol of the 26th Colloquy, 1-13.

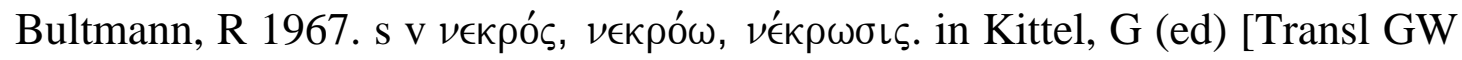
Bromiley], Theological Dictionary of the New Testament, vol. $4(\Lambda-\mathrm{N})$. Grand Rapids: Eerdmans, 892-895.

Coetzee, J C 1984. Paulus se eskatologiese prediking in Du Toit, A B (ed), Handleiding by die Nuwe Testament. Band V. Die Pauliniese Briewe: Inleiding en Teologie. Pretoria: NG Kerkboekhandel Transvaal, 332-364.

Collins, J J 2002. Death and Afterlife in Barton, J (ed), The Biblical World, Vol 2. London \& New York: Routledge, 357-77. 
Crossan, J D and Reed, J L 2004. In Search of Paul. How Jesus's Apostle opposed Rome's Empire with God's Kingdom. A New Vision of Paul's Words and World. New York: Harper: SanFrancisco.

Croy, N C 2003. "To Die Is Gain" (Philippians 1:19-26): Does Paul Contemplate Suicide? Journal of Biblical Literature 122(3), 517-31.

Daube, D 1962. Death as a Release in the Bible. Novum Testamentum 5(2/3), 82-104.

Deacy, C 2001. Screen Christologies. Redemption and the Medium of Film. Religion, Culture and Society. Cardiff: University of Wales Press.

Droge, A J 1988. Mori lucrum: Paul and Ancient Theories of Suicide. Novum Testamentum 30, 263-86.

-, 1992. Suicide in Freedman, D N (ed), The Anchor Bible Dictionary, vol. 6 (Si-Z). New York: Doubleday, 225-231.

Frederickson, D E 2000. Paul Playfully on Time and Eternity. Dialog 39(1): 21-6.

Georgi, D 1991. Theocracy in Paul's Praxis and Theology (Gott Auf Den Kopf Stellen [Trans. DE Green]). Minneapolis: Fortress Press.

Gulley, N R 1992. Death: New Testament in Freedman, D N (ed), The Anchor Bible Dictionary, vol. 2 (D-G). New York: Doubleday, 110-111.

Hays, R B 1989. Echoes of Scripture in the Letters of Paul. New Haven: Yale University Press.

Howell, D N jr 1993. Pauline Thought in the History of Interpretation. Bibliotheca Sacra 150(599), 303-326.

Jasper, D 1997. On Systematizing the Unsystematic: A Response in Marsh C and Ortiz, G (eds), Explorations in Theology and Film. Movies and Meaning. Oxford: Blackwell, 235-44.

Kaiser, O and Lohse, E 1981. Death \& Life. Biblical Encounters Series [trans. J E Steely]. Nashville: Abingdon.

Keck, L. 2006. Paul in New Testament Theology: Some Preliminary Remarks. in Rowland, C \& Tuckett, C (eds), The Nature of New Testament Theology. Essays in Honour of Robert Morgan. London: Blackwell, 109-22.

Koch, HJ. 2005. Suicides and Suicide Ideation in the Bible: An Empirical Survey. Acta Psychiatrica Scandinavica 112, 167-72.

Lieu, J, J North and Rajak, T 1992. Introduction in Lieu, J, North, J \& Rajak, T (eds), The Jews among Pagans and Christians. London \& New York: Routledge, 1-8.

Luz, U 1994. Matthew in History. Interpretation, Influence, and Effects. Minneapolis: Fortress.

Martin-Achard, R 1992. Resurrection - Old Testament in Freedman, D N (ed), The Anchor Bible Dictionary, vol. 5 (O-Sh), [transl. T Prendergast]. New York: Doubleday, 680-684. 
Miles, M R 1996. Seeing and Believing. Religion and Values in the Movies. Boston: Beacon.

Murray, R 1982. Jews, Hebrews and Christians. Some Needed Distinctions. Novum Testamentum 24(3): 194-208.

Nickelsburg, G W 1992. Resurrection - Early Judaism and Christianity in Freedman, D N (ed), The Anchor Bible Dictionary, vol. 5 (O-Sh). New York: Doubleday, 684-691.

Olson, HS. 1991. A Seamless Garment - African Understanding of Wholeness. Currents in Theology and Mission 18(4), 273-81.

Palmer, D W 1975. "To Die Is Gain" (Philippians I 21). Novum Testamentum 17(3): 203-18.

Parkes, C M, Laungani, P \& Young, B 2003. Introduction in Parkes, C M, Laungani, P \& Young, B (eds), Death and Bereavement across Cultures, Psychology / Counselling / Religion. Hove \& New York: BrunnerRoutledge, 3-9.

Perkins, P 1988. Reading the New Testament. An Introduction. Rev ed. Mahwah: Paulist.

Richards, K H 1992. Death: Old Testament in Freedman, D N (ed), The Anchor Bible Dictionary, vol. 2 (D-G), New York: Doubleday, 108-110.

Sabou, S 2005. Between Horror and Hope. Paul's Metaphorical Language of "Death" in Romans 6:1-11. Paternoster Biblical Monographs. Carlisle: Paternoster.

Schreiber, S 2003. Paulus im 'Zwischenzustand': Phil 1.23 und die Ambivalnez des Sterbens als Provokation. New Testament Studies 49(4), 336-59.

Shutte, A. 1988. Umuntu Ngumuntu Ngabantu: an African conception of humanity. Paper delivered at the Annual PSSA conference. Segal, A F 2004. Life after Death. A History of the Afterlife in Western Religion. New York: Doubleday.

Tabor, J D 1992. Martyr, Martyrdom in Freedman, D N (ed), The Anchor Bible Dictionary, vol. 4 (K-N). New York: Doubleday, 574-579.

Walter, T 2003. Secularization in Parkes, C M, Laungani, P \& Young, B (eds), Death and Bereavement across Cultures, Psychology / Counselling / Religion. Hove \& New York: Brunner-Routledge, 166-87.

Wink, W 1992. Engaging the Powers. Discernment and Resistance in a World of Domination. Minneapolis: Fortress.

Young, F \& Ford, D F 1987. Meaning and Truth in 2 Corinthians. Biblical Foundations in Theology. London: SPCK. 